\title{
Dosage Calculation for Intravenous Thrombolysis of Ischemic Stroke: To Weigh or to Estimate?
}

\author{
Andreas Ragoschke-Schumm ${ }^{a}$ Asem Razouk ${ }^{a}$ Martin Lesmeister ${ }^{a}$ \\ Stefan Helwig ${ }^{a}$ Iris Q. Grunwald ${ }^{\text {b, }}$ Klaus Fassbender ${ }^{a}$ \\ ${ }^{a}$ Department of Neurology, Saarland University Medical Center, Homburg, Germany; \\ ${ }^{b}$ Department of Neuroscience, Faculty of Medical Science, Postgraduate Medical \\ Institute, Anglia Ruskin University, Chelmsford, UK; ' Southend University Hospital, \\ Southend-on-Sea, UK
}

\section{Keywords}

Stroke teams - Acute stroke treatment - Ischemic stroke $\cdot$ Clinical trial · Tissue plasminogen activator $\cdot$ Thrombolysis - Weight

\begin{abstract}
Background: Estimation is a widely used method of assessing the weight of patients with acute stroke. Because the dosage of tissue plasminogen activator (TPA) is weight-dependent, errors in estimation lead to incorrect dosing. Methods: We installed a ground-level scale in the computed tomography (CT) suite of our hospital and also integrated a scale into the CT table of our Mobile Stroke Unit in order to prospectively assess the differences between reported, estimated, and measured weights of acute stroke patients. An independent rater asked patients to report their weight. The patients' weights were also estimated by the treating physician and measured with a scale. Differences between reported, estimated, and measured weights were analyzed statistically. Results: For 100 consecutive patients, weighing was possible without treatment delays. Weights estimated by the physician diverged from measured weights by $10 \%$ or more for 27 patients and by $20 \%$ or more for 6 patients. Weights reported by the patient diverged from measured weights by $10 \%$ or more for 12 patients. Weights reported by the patients differed significantly less from measured weights (mean, $4.1 \pm 3.1 \mathrm{~kg}$ ) than did weights estimated by the physician $(5.7 \pm 4.4 \mathrm{~kg} ; p=0.003)$. Conclusion:
\end{abstract}

All original data sheets exist in paper form and can be provided by the authors. 
Ragoschke-Schumm et al.: Weight Assessment in Acute Stroke prior to Intravenous Thrombolysis

This first prospective study of weight assessment in acute stroke shows that the use of an easily accessible scale makes it feasible to weigh patients with acute stroke without the treatment delay associated with additional patient transfers. Physicians' estimates of patients' weights demonstrated substantial aberrations from measured weights. Avoiding these deviations would improve the accuracy of tPA dosage.

(C) 2017 The Author(s)

Published by S. Karger AG, Basel

\section{Introduction}

Although several recent trials have achieved positive results with mechanical recanalization after acute ischemic stroke with large-vessel occlusion [1-5], intravenous thrombolysis (IVT) is still the most important acute treatment for the vast majority of ischemic stroke patients [6-9]. The dosage of tissue plasminogen activator (tPA) depends on the patient's weight: the approved dosage is $0.9 \mathrm{mg} / \mathrm{kg}$ to a maximum dose of $90 \mathrm{mg}$. However, uncertainties remain whether the current dosage regimen is optimal.

Most reports of randomized controlled trials have not stated how patients' weights were assessed or whether weights were only estimated; only the report of the European Cooperative Acute Stroke Study II (ECASS II) states that most weights were estimated [8]. More precise data were presented in the Safe Implementation of Thrombolysis in Stroke-International Stroke Thrombolysis (SITS-ISTR) Registry: $14.6 \%$ of patients' weights were measured, whereas the remaining were estimated [10]. Clinical surveys have shown that health care professionals most commonly assess a patient's weight by asking the patient or the patient's caregiver or by roughly estimating the patient's weight [11]. Only a small minority of hospitals actually weigh the patient before thrombolysis is administered.

Findings about whether inaccurate assessment of weight affects clinical outcomes are mostly retrospective and sometimes contradictory. However, a growing body of evidence suggests that imprecise dosage may negatively influence outcome [12-14]. No prospective trials have determined the accuracy of weights reported by the patient or estimated by the treating medical staff in the acute setting.

When asked, clinicians argue that weighing the patient is either time consuming or impossible because of the patient's immobility and the need to transfer the patient in a seated or upright position. However, these limitations can now be overcome by ground-level scales that allow the patient and the emergency medical service stretcher to be placed directly on the scale, without patient transfer. In addition, certain computed tomography (CT) tables now contain an integrated scale.

After the implementation of a ground-level scale in our hospital and the integration of a scale into the CT table of our Mobile Stroke Unit [15], we prospectively compared the weights reported by the patients, those estimated by health care professionals, and those measured with a scale.

\section{Methods}

Patients with suspected acute stroke or transient ischemic attack who were admitted to our hospital were included in this study. Written informed consent was obtained from all patients or their caregivers before the study. The study was performed in accordance with our clinical ethical guidelines and was approved by the ethics committee of the Chamber of Physicians of the Saarland. 
Ragoschke-Schumm et al.: Weight Assessment in Acute Stroke prior to Intravenous Thrombolysis

Fig. 1. a Ground-level scale and display (arrows) in the computed tomography (CT) suite of the hospital, allowing weighing of the patient during the handover procedure without additional transfer. b A scale integrated into the CT table of the Mobile Stroke Unit for automatic weighing of the patient. Arrow shows the display of the scale.
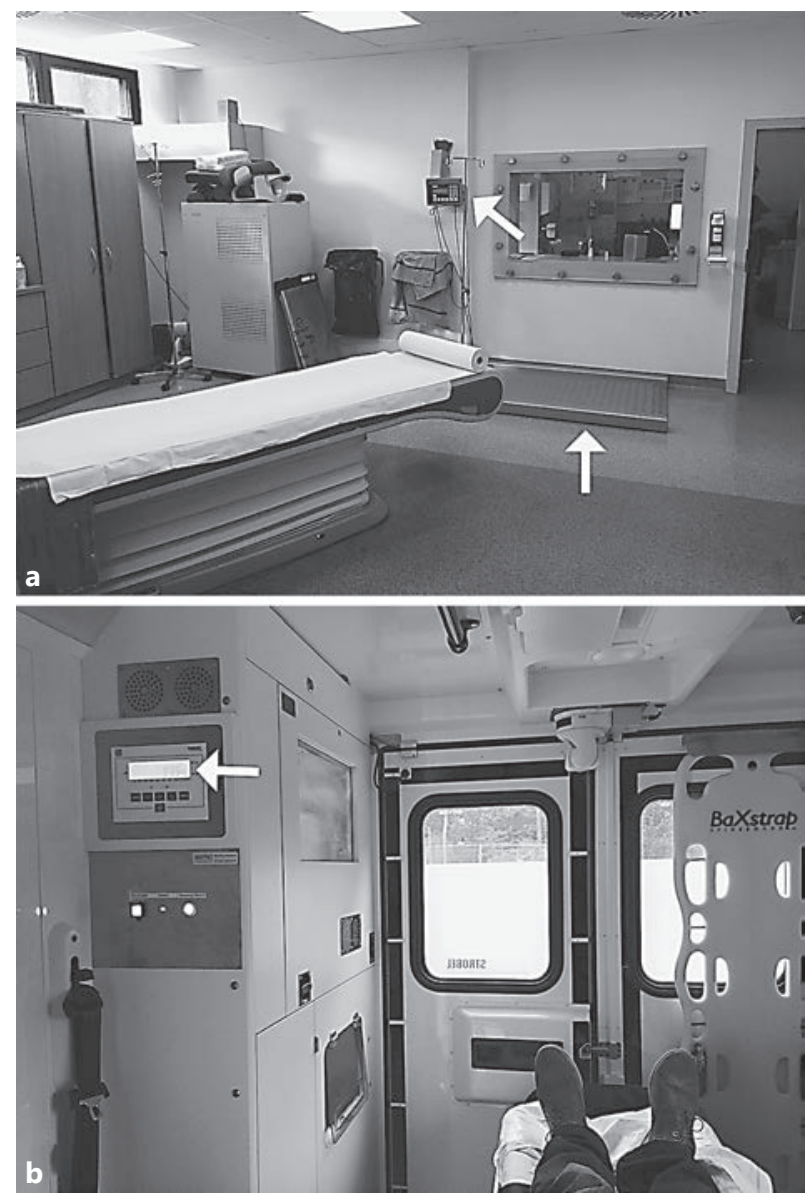

\section{Measuring Weight with the Ground-Level Scale}

In our hospital, patients are admitted to the CT suite, which contains a point-of-care laboratory so that treatment delays can be reduced [16]. A ground-level scale (Soehnle, Nassau, Germany; Fig. 1a) was installed in this suite so that paramedics can place the patient directly onto it upon entering the room. Thus, the patient is weighed together with the stretcher. The patient is then transferred to the CT table, and the weight of the stretcher is determined with the ground-level scale. The difference between the two results is the patient's weight. Treatment delays are avoided by measuring weight during the handover of the patient from the emergency physician to the treating neurologist.

\section{Measuring Weight in the Mobile Stroke Unit}

In the Mobile Stroke Unit, a scale (Soehnle; Fig. 1b) has been integrated into the CT table. Medical equipment such as monitors is removed from the stretcher during weighing. The stretcher's weight is automatically subtracted from the measured weight. The scale in the CT table of the Mobile Stroke Unit has been successfully used for more than 50 patients with no treatment delays.

\section{Comparing Reported, Estimated, and Measured Weights}

In the hospital's CT suite, an independent rater asked the patients to report their own weight. If the patient was aphasic or otherwise unable to answer, the patient's caregiver was 
Ragoschke-Schumm et al.: Weight Assessment in Acute Stroke prior to Intravenous

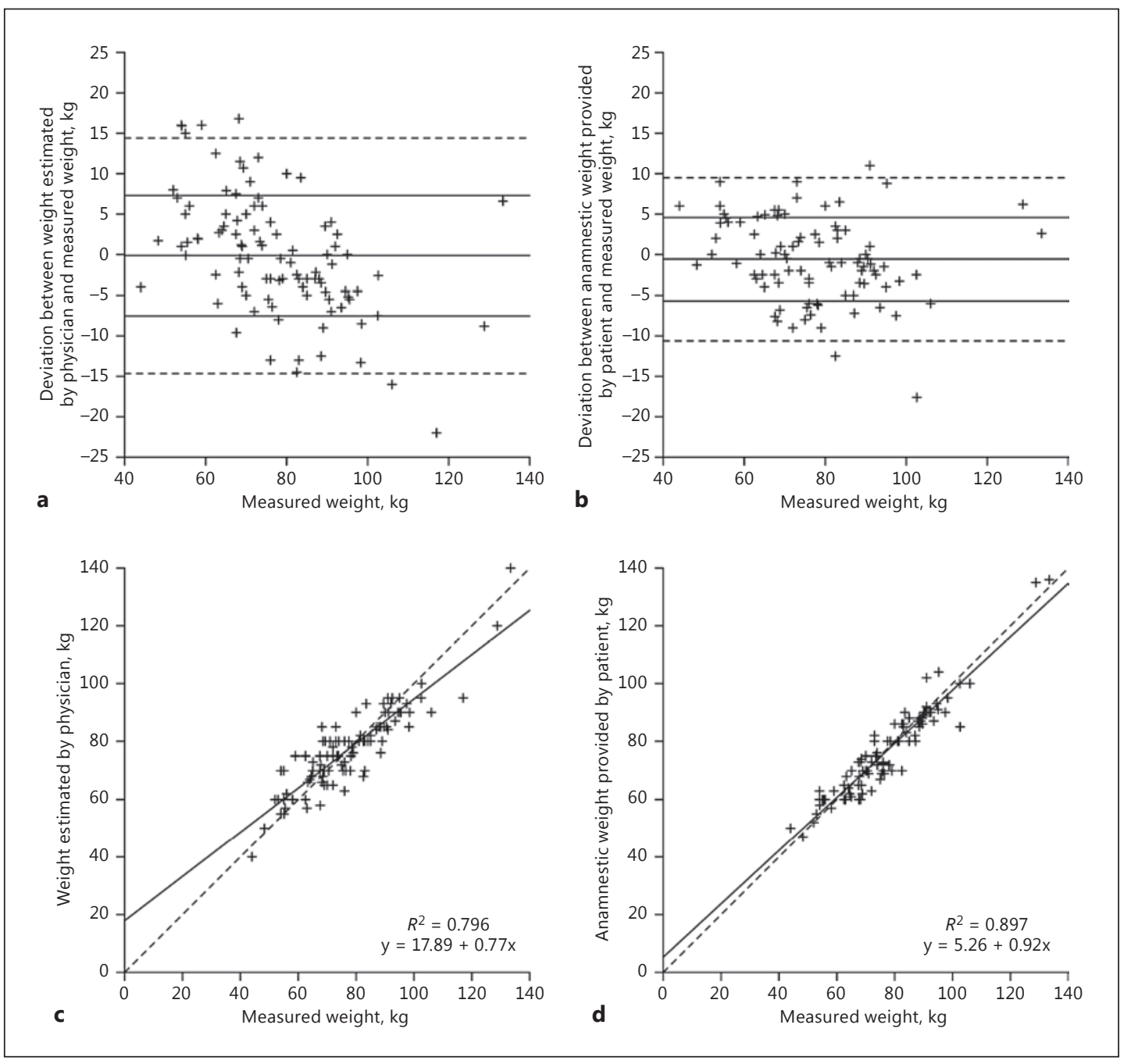

Fig. 2. Modified Bland-Altman plot showing deviation of weight estimated by health care professionals from measured weight (a) and deviation of weight reported by the patients from measured weight (b). The solid lines indicate means and standard deviations; the dashed lines, the 1.96-fold standard deviations. Plot shows weight estimated by the health care professionals (c) and weight reported by the patients against measured weight (d). The solid lines display simple linear regression; the dashed lines, the equality of estimated and measured weights.

asked to provide the weight. Next, the treating neurologist, who was unaware of either the reported or the measured weight, estimated the patient's weight. Deviations of reported and estimated weights from measured weights were analyzed statistically (Fig. 2).

\section{Statistics}

Statistical analyses were performed with IBM SPSS Statistics for Windows, version 23.0.0.2 (IBM Corporation, Armonk, NY, USA; released 2015). The difference between the absolute values of deviations of reported and estimated weights from measured weights were analyzed with $t$ tests for paired variables. Statistical significance was set at the level of $p<0.05$. 


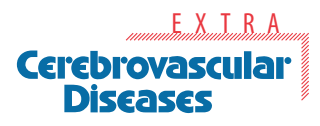

Table 1. Patients' characteristics $(n=100)$

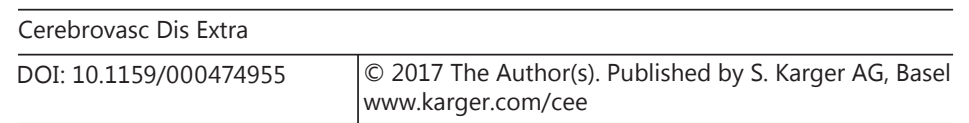

Ragoschke-Schumm et al.: Weight Assessment in Acute Stroke prior to Intravenous Thrombolysis

\begin{tabular}{lc}
\hline Age, years & $71.5(20-92)$ \\
Men & 47 \\
Women & 53 \\
NIHSS score at admission & $4(0-40)$ \\
mRS score at admission & $2(0-5)$ \\
NIHSS score at discharge & $1(0-40)$ \\
mRS score at discharge & $1(0-6)$ \\
Patients unable to report weight & 8 \\
Average measured weight, kg & $76.0(44.0-133.4)$ \\
Stroke mimics & 10 \\
IVT, mechanical recanalization, or both & 24 \\
Primary ICH & 2 \\
Secondary ICH & 3 \\
Death & 1
\end{tabular}

Continuous data shown as median (range), except if indicated otherwise. NIHSS, National Institutes of Health Stroke Scale; mRS, modified Rankin Scale; IVT, intravenous thrombolysis; ICH, intracranial hemorrhage.

\section{Results}

\section{Patients}

This study assessed 100 consecutive patients with suspected acute stroke (53 women, 47 men; median age, 71.5 years). Patients' characteristics are displayed in Table 1 . Ten of the patients had stroke mimics, and 2 had primary intracranial hemorrhage. IVT, mechanical recanalization, or both were necessary for 24 patients, including 3 who experienced secondary hemorrhagic transformation or bleeding into the infarct, one of these with symptomatic bleeding. The median National Institutes of Health Stroke Scale score (NIHSS) was 4 (range, $0-40$ ) at the time of admission and 1 (range, $0-40$ ) at the time of discharge. The median modified Rankin Scale score was 2 (range, $0-5$ ) at the time of admission and 1 (range, 0-6) at the time of discharge.

\section{Estimated and Actual Weights}

Eight patients could not report their own weight because of aphasia $(n=7)$ or agitation $(n=1)$. The median measured weight of the patients was $76.0 \mathrm{~kg}$ (range, 44.0-133.4 kg). Weighing of all 100 patients was performed during the routine handover procedure with no delays.

\section{Comparison between Estimated and Measured Weight}

The weights estimated by the physician diverged from actual weights by $10 \%$ or more for 27 patients and by $20 \%$ or more for 6 patients. In absolute values, 17 estimated weights deviated from measured weights by $10 \mathrm{~kg}$ or more; the extremes of estimated weights were $22 \mathrm{~kg}$ too light and $16.8 \mathrm{~kg}$ too heavy (Fig. 2a).

For the 92 patients for whom weights could be reported, 12 weights (13\%) diverged by $10 \%$ or more from measured weights; there were no deviations of $20 \%$ or more. In absolute values, the weights of 3 patients (3.3\%) deviated by $10 \mathrm{~kg}$ or more from measured weights; the extremes of estimated weights were $17.6 \mathrm{~kg}$ too light and $11 \mathrm{~kg}$ too heavy (Fig. 2b). Reported weights differed significantly less from measured weights (mean deviation, $4.1 \pm$ $3.1 \mathrm{~kg})$ than did estimated weights ( $5.7 \pm 4.4 \mathrm{~kg} ; p=0.003$; Fig. $2 \mathrm{c}, \mathrm{d})$. 


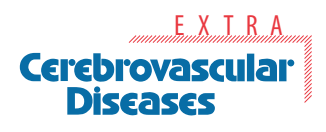

\begin{tabular}{l|l}
\hline Cerebrovasc Dis Extra \\
\hline DOI: $10.1159 / 000474955$ & $\begin{array}{l}\text { (c) 2017 The Author(s). Published by S. Karger AG, Basel } \\
\text { www.karger.com/cee }\end{array}$ \\
\hline
\end{tabular}

Ragoschke-Schumm et al.: Weight Assessment in Acute Stroke prior to Intravenous Thrombolysis

\section{Discussion}

This prospective study shows that weighing acute stroke patients in the stroke treatment room or in a mobile stroke unit is feasible without treatment delays and that deviations between estimated and real weights are substantial: estimations of weight by health care professionals diverged by $10 \%$ or more from actual weight for $27 \%$ of patients. These results are consistent with the findings of earlier studies suggesting that estimation is prone to severe errors. Breuer et al. [12] found variations of as much as $42 \%$ between estimated and actual weights; the deviation was more than $10 \%$ for every third patient. Similar results were reported by Lorenz et al. [17].

Because the dosage of tPA is based on the patient's weight, the risk of misdosing exists for a large number of patients. Our findings of frequent incorrect estimates led us to question whether weight assessment based on estimation or on nomograms alone is still justified. While the current dosage of tPA has been approved due to the results of the NINDS trial, there remain uncertainties regarding the ideal dosage and dosage corridor. Data from registries do not indicate a substantial risk [18]. One recent study, which assessed patients' actual weights after IVT, compared a standard dose group with groups receiving overdosage or underdosage of IVT; the study found no evidence that misdosage had any effects on clinical outcome. However, these findings could be explained by the fact that this relatively small study $(n=$ 272) may have been underpowered to address such a study question [19].

On the other hand, it is implausible to assume that misdosing of a highly effective and weight-adapted drug would have no effect on clinical results, because a dose-effect relationship can be expected. This suggestion is supported by a growing body of evidence indicating negative outcomes due to misdosing. Sahlas et al. [14] reported that overdosed patients exhibited impaired outcome and more episodes of intracranial bleeding, and Breuer et al. [12] found that precise dosages $(0.8-1.0 \mathrm{mg} / \mathrm{kg})$ are required for optimal recanalization. Similarly, Wahlgren et al. [13] reported that underdosage may be associated with impaired clinical outcome. Compared with nonobese patients, obese patients exhibit a lower rate of intracranial hemorrhage because of systematic underdosing of tPA (the ceiling dose is $90 \mathrm{mg}$ ). Such underdosing reduces both the beneficial and the adverse pharmacological effects of the drug [20].

A survey of 119 German stroke units found that $80.5 \%$ always or frequently estimate patients' weights. Only $4.2 \%$ of these stroke units always weigh patients, and an additional $7.6 \%$ frequently weigh them. The most frequent answers to the question of why patients are not weighed were the following: "No opportunity to weigh patients in supine position;" "time delay;" "scale is unpractical;" "scale is too far away;" and "no scale is available." [11] Similar results were found in the SITS-ISTR Registry, which reported that only $14.6 \%$ of patients were weighed; weights were estimated for $84.6 \%$ of patients [10].

Nomograms based on anthropometric data, such as height, waist circumference, and hip size, have been proposed for overcoming the problems of imprecise weight estimates, but such calculating devices are time-consuming. Furthermore, even with this approach, deviations of more than 10\% have been reported [20]. Moreover, these surveys indicate that nomograms are almost never used in actual patient care, at least in the countries in which the survey was performed. The recently published ENCHANTED trial, involving predominantly Asian patients, compared low dose $(0.6 \mathrm{mg} / \mathrm{kg})$ versus standard dose of tPA and did not show the noninferiority of the lower dose with respect to death and disability at 90 days, but there were significantly fewer symptomatic intracranial hemorrhages [21].

Another finding of these surveys was that many hospitals do not have scales suitable for weighing acute stroke patients. This fact could be due to the potentially high costs of such scales. The commercially available ground-level scale for hospital use and the scale integrated in the CT table cost EUR/USD 3,000 each. However, overdosing of tPA is also costly; over time, 
avoiding these costs could conceivably offset the cost of a scale. Additionally, avoiding overdosing would allow safer and more effective treatment of acute stroke patients. As our study shows, using the ground-level scale or a scale integrated into the CT table does not increase delays in acute stroke management; therefore, there is no reason to omit actual weighing of the thrombolysis candidate.

This study has some limitations. Although we were able to demonstrate substantial aberrations between estimated and measured weights, we could not determine whether these aberrations would lead to impaired clinical outcome. Without blinded randomization between estimated weights and measured weights it is not possible to know whether differences between them have an effect on outcome. On the other hand, for ethical reasons, it is very unlikely that such a randomized trial could be performed once a scale has already been installed.

In conclusion, in this prospective study on weight assessment in acute stroke patients, weighing patients with acute stroke on a ground-level scale or a scale integrated into the CT table is feasible and avoids the treatment delays associated with additional transfer of the patients. Estimates of patients' weight by health care professionals and reports of weight by the patients themselves diverge substantially from patients' measured weights. Measuring patients' weight with a scale would avoid these deviations and would improve the accuracy of tPA dosing.

\section{Disclosure Statement}

The authors declare that there is no conflict of interest.

\section{Funding Sources}

This research received no specific grant from any funding agency in the public, commercial, or not-for-profit sectors.

\section{References}

1 Berkhemer OA, Fransen PS, Beumer D, van den Berg LA, Lingsma HF, Yoo AJ, Schonewille WJ, Vos JA, Nederkoorn PJ, Wermer MJ, van Walderveen MA, Staals J, Hofmeijer J, van Oostayen JA, Lycklama à Nijeholt GJ, Boiten J, Brouwer PA, Emmer BJ, de Bruijn SF, van Dijk LC, Kappelle LJ, Lo RH, van Dijk EJ, de Vries J, de Kort PL, van Rooij WJ, van den Berg JS, van Hasselt BA, Aerden LA, Dallinga RJ, Visser MC, Bot JC, Vroomen PC, Eshghi O, Schreuder TH, Heijboer RJ, Keizer K, Tielbeek AV, den Hertog HM, Gerrits DG, van den Berg-Vos RM, Karas GB, Steyerberg EW, Flach HZ, Marquering HA, Sprengers ME, Jenniskens SF, Beenen LF, van den Berg R, Koudstaal PJ, van Zwam WH, Roos YB, van der Lugt A, van Oostenbrugge RJ, Majoie CB, Dippel DW: A randomized trial of intraarterial treatment for acute ischemic stroke. N Engl J Med 2015;372:11-20.

-2 Jovin TG, Chamorro A, Cobo E, de Miquel MA, Molina CA, Rovira A, San Román L, Serena J, Abilleira S, Ribó M, Millán M, Urra X, Cardona P, López-Cancio E, Tomasello A, Castaño C, Blasco J, Aja L, Dorado L, Quesada H, Rubiera M, Hernandez-Pérez M, Goyal M, Demchuk AM, von Kummer R, Gallofré M, Dávalos A: Thrombectomy within $8 \mathrm{~h}$ after symptom onset in ischemic stroke. N Engl J Med 2015;372:2296-2306.

-3 Saver JL, Goyal M, Bonafe A, Diener HC, Levy EI, Pereira VM, Albers GW, Cognard C, Cohen DJ, Hacke W, Jansen O, Jovin TG, Mattle HP, Nogueira RG, Siddiqui AH, Yavagal DR, Baxter BW, Devlin TG, Lopes DK, Reddy VK, du Mesnil de Rochemont R, Singer OC, Jahan R: Stent-retriever thrombectomy after intravenous t-PA versus t-PA alone in stroke. N Engl J Med 2015;372:2285-2295.

4 Goyal M, Demchuk AM, Menon BK, Eesa M, Rempel JL, Thornton J, Roy D, Jovin TG, Willinsky RA, Sapkota BL, Dowlatshahi D, Frei DF, Kamal NR, Montanera WJ, Poppe AY, Ryckborst KJ, Silver FL, Shuaib A, Tampieri D, Williams D, Bang OY, Baxter BW, Burns PA, Choe H, Heo JH, Holmstedt CA, Jankowitz B, Kelly M, Linares G, Mandzia JL, Shankar J, Sohn SI, Swartz RH, Barber PA, Coutts SB, Smith EE, Morrish WF, Weill A, Subramaniam S, Mitha AP, Wong JH, Lowerison MW, Sajobi TT, Hill MD: Randomized assessment of rapid endovascular treatment of ischemic stroke. N Engl J Med 2015;372:1019-1030. 
Ragoschke-Schumm et al.: Weight Assessment in Acute Stroke prior to Intravenous Thrombolysis

5 Campbell BC, Mitchell PJ, Kleinig TJ, Dewey HM, Churilov L, Yassi N, Yan B, Dowling RJ, Parsons MW, Oxley TJ, Wu TY, Brooks M, Simpson MA, Miteff F, Levi CR, Krause M, Harrington TJ, Faulder KC, Steinfort BS, Priglinger M, Ang T, Scroop R, Barber PA, McGuinness B, Wijeratne T, Phan TG, Chong W, Chandra RV, Bladin CF, Badve M, Rice H, de Villiers L, Ma H, Desmond PM, Donnan GA, Davis SM: Endovascular therapy for ischemic stroke with perfusion-imaging selection. N Engl J Med 2015;372:1009-1018.

6 The National Institute of Neurological Disorders and Stroke rt-PA Stroke Study Group: Tissue plasminogen activator for acute ischemic stroke. N Engl J Med 1995;333:1581-1587.

7 Hacke W, Kaste M, Fieschi C, Toni D, Lesaffre E, von Kummer R, Boysen G, Bluhmki E, Höxter G, Mahagne MH: Intravenous thrombolysis with recombinant tissue plasminogen activator for acute hemispheric stroke. The European Cooperative Acute Stroke Study (ECASS). JAMA 1995;274:1017-1025.

-8 Hacke W, Kaste M, Fieschi C, von Kummer R, Davalos A, Meier D, Larrue V, Bluhmki E, Davis S, Donnan G, Schneider D, Diez-Tejedor E, Trouillas P: Randomised double-blind placebo-controlled trial of thrombolytic therapy with intravenous alteplase in acute ischemic stroke (ECASS II). Lancet 1998;352:1245-1251.

-9 Hacke W, Kaste M, Bluhmki E, Brozman M, Dávalos A, Guidetti D, Larrue V, Lees KR, Medeghri Z, Machnig T, Schneider D, von Kummer R, Wahlgren N, Toni D: Thrombolysis with alteplase 3-4.5 h after acute ischemic stroke. N Engl J Med 2008;359:1317-1329.

10 Diedler J, Ahmed N, Glahn J, Grond M, Lorenzano S, Brozman M, Sykora M, Ringleb P: Is the maximum dose of $90 \mathrm{mg}$ alteplase sufficient for patients with ischemic stroke weighing $>100 \mathrm{~kg}$ ? Stroke 2011;42:1615-1620.

11 Cassier-Woidasky AK: To weigh or to estimate for exact dosage of thrombolysis - ways to get the body-weight in German stroke units. Akt Neurol 2015;42:205-211.

12 Breuer L, Nowe T, Huttner HB, Blinzler C, Kollmar R, Schellinger PD, Schwab S, Köhrmann M: Weight approximation in stroke before thrombolysis: the WAIST-Study: a prospective observational "dose-finding" study. Stroke 2010;41:2867-2871.

13 Wahlgren N, Ahmed N, Eriksson N, Aichner F, Bluhmki E, Dávalos A, Erilä T, Ford GA, Grond M, Hacke W, Hennerici MG, Kaste M, Köhrmann M, Larrue V, Lees KR, Machnig T, Roine RO, Toni D, Vanhooren G; Safe Implementation of Thrombolysis in Stroke-MOnitoring STudy Investigators: Multivariable analysis of outcome predictors and adjustment of main outcome results to baseline data profile in randomized controlled trials: Safe Implementation of Thrombolysis in Stroke-Monitoring Study (SITS-MOST). Stroke 2008;39:3316-3322.

14 Sahlas DJ, Gould L, Swartz RH, Mohammed N, McNicoll-Whiteman R, Naufal F, Oczkowski W: Tissue plasminogen activator overdose in acute ischemic stroke patients linked to poorer functional outcomes. J Stroke Cerebrovasc Dis 2014;23:155-159.

15 Walter S, Kostopoulos P, Haass A, Keller I, Lesmeister M, Schlechtriemen T, Roth C, Papanagiotou P, Grunwald I, Schumacher H, Helwig S, Viera J, Körner H, Alexandrou M, Yilmaz U, Ziegler K, Schmidt K, Dabew R, Kubulus D, Liu Y, Volk T, Kronfeld K, Ruckes C, Bertsch T, Reith W, Fassbender K: Diagnosis and treatment of patients with stroke in a mobile stroke unit versus in hospital: a randomised controlled trial. Lancet Neurol 2012;11: 397-404.

-16 Ragoschke-Schumm A, Yilmaz U, Kostopoulos P, Lesmeister M, Manitz M, Walter S, Helwig S, Schwindling L, Fousse M, Haass A, Garner D, Körner H, Roumia S, Grunwald I, Nasreldein A, Halmer R, Liu Y, Schlechtriemen T, Reith W, Fassbender K: "Stroke room:" diagnosis and treatment at a single location for rapid intraarterial stroke treatment. Cerebrovasc Dis 2015;40:251-257.

17 Lorenz MW, Graf M, Henke C, Hermans M, Ziemann U, Sitzer M, Foerch C: Anthropometric approximation of body weight in unresponsive stroke patients. J Neurol Neurosurg Psychiatry 2007;78:1331-1336.

-18 Messé SR, Kasner SE, Cucchiara BL, Demchuk A, Tanne D, Ouyang B, Levine SR; NINDS t-PA Stroke Study Group: Dosing errors did not have a major impact on outcome in the NINDS t-PA stroke study. J Stroke Cerebrovasc Dis 2011;20:236-240.

19 Aulicky P, Rabinstein A, Seet RC, Neumann J, Mikulik R: Dosing of tissue plasminogen activator often differs from $0.9 \mathrm{mg} / \mathrm{kg}$, but does not affect the outcome. J Stroke Cerebrovasc Dis 2013;22:1293-1297.

20 Hassan AE, Chaudhry SA, Jani V, Grigoryan M, Khan AA, Adil MM, Qureshi AI: Is there a decreased risk of intracerebral hemorrhage and mortality in obese patients treated with intravenous thrombolysis in acute ischemic stroke? J Stroke Cerebrovasc Dis 2013;22:545-549.

-21 Anderson CS, Robinson T, Lindley RI, Arima H, Lavados PM, Lee TH, Broderick JP, Chen X, Chen G, Sharma VK, Kim JS, Thang NH, Cao Y, Parsons MW, Levi C, Huang Y, Olavarría VV, Demchuk AM, Bath PM, Donnan GA, Martins S, Pontes-Neto OM, Silva F, Ricci S, Roffe C, Pandian J, Billot L, Woodward M, Li Q, Wang X, Wang J, Chalmers J; ENCHANTED Investigators and Coordinators: Low-dose versus standard-dose intravenous alteplase in acute ischemic stroke. N Engl J Med 2016;374:2313-2323. 